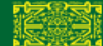

FIKRI
Fikri: Jurnal Kajian Agama, Sosial dan Budaya

Volume 3, Nomor 2, Desember 2018

DOI: https://doi.org/10.25217/jf.v3i2.308

http://journal.iaimnumetrolampung.ac.id/index.php/jf

\title{
KONSEP POLITIK ISLAM KULTURAL PERSPEKTIF NURCHOLISH MADJID
}

\author{
Mohammad Taufiq Rahman ${ }^{1}$, Asep Saeful Mimbar ${ }^{2}$ \\ ${ }^{1}$ Universitas Islam Negeri Sunan Gunung Jati, Bandung \\ ${ }^{2}$ Universitas Islam Negeri Sunan Gunung Jati, Bandung \\ * CORRESPONDENCE: $\square$ fikrakoe@uinsgd.ac.id
}

\begin{abstract}
This article is about the political thought of Islam Nurcholish Madjid. For most Islamic societies, Nurcholish is the big thinkers who followed pemikiran-pemikirannya. What is discussed here is especially points where Nurcholish makes a political statementstatement is then taken by colleagues in his day and thereafter. The most notable being discussed here is a thought-provoking cultural politics in the era of new order Nurcholish, who then lashed with political thought at the beginning of the Reformation period. Research methods this article is using a qualitative approach, while the nature of this normative and sociological research. This article is the kind of research libraries or commonly called with (library research). This article aims to find out how the concept of political Islam cultural Perspective Nurcholish Madjid. Results or conclusions of the article is that of religious thought, in political thought Nurcholish asserted any necessity of openness, both Muslims and non-Muslims in Indonesia not to happen "the price of death". Each party in the political arena, according to him, Indonesia must continue to do the bargaining and accommodation of interests each for the creation of a common interest.
\end{abstract}

\section{Abstrak}

Artikel ini tentang pemikiran politik Islam Nurcholish Madjid. Bagi sebagian kalangan Islam, Nurcholish adalah pemikir besar yang diikuti pemikiran-pemikirannya. Apa yang didiskusikan di sini terutama adalah poin-poin di mana Nurcholish membuat statemenstatemen politik yang kemudian ditanggapi oleh kolega-kolega pada zamannya dan zaman sesudahnya. Yang paling menonjol yang dibahas di sini adalah pemikiran politik kultural Nurcholish pada zaman Orde Baru, yang kemudian disangkutkan dengan pemikiran politis pada zaman Reformasi awal. Metode penelitian artikel ini adalah menggunakan pendekatan kualitatif, sedangkan sifat penelitian ini normatif dan sosiologis. Jenis artikel ini adalah penelitian kepustakaan atau biasa disebut dengan (library research). Artikel ini bertujuan untuk mengetahui bagaimanakah konsep politik Islam cultural Perspektif Nurcholish Madjid. Hasil atau kesimpulan artikel ini adalah bahwa pemikiran keagamaan, dalam pemikiran politik Nurcholish pun menegaskan perlunya keterbukaan, baik dari kalangan Muslim maupun non-Muslim di Indonesia agar tidak terjadi "harga mati". Masing-masing pihak yang hidup di arena politik Indonesia, menurutnya, harus terus melakukan tawar menawar dan akomodasi kepentingan masing-masing demi terciptanya kepentingan bersama.
Article Info

Article History

Received : 14-09-2018

Revised : 29-12-2018

Accepted : 31-12-2018

\section{Keywords:}

Islamic Culture;

Islamic Politic;

The Islamic State;

\section{Histori Artikel}

Diterima: 14-09-2018

Direvisi: $29-12-2018$

Disetujui: $31-12-2018$

\section{Kata Kunci}

Budaya Islam;

Politik Islam;

Negara Islam;

\section{A. Pendahuluan}

Buku Nurcholish, Khazanah Intelektual Islam (1985) menunjukkan bahwa ia selalu berupaya untuk mencari akar tradisi Islam. Begitu pula halnya dengan tradisi politik Islam. Nurcholish memang sangat radikal dalam pencarian tradisi ini, yaitu kembali ke akar-akar Islam periode awal. Itulah barangkali salah satu sifat seorang filosof: radikal. Memang pencarian model politik Islam pada periode awal ini bukan khas Nurcholish. Pencarian Islam asli ini telah menjadi "imajinasi politik Islam" di seluruh dunia[1]. Dengan demikian, telah terjadi kesamaan akar tradisi politik Islam, yaitu masa Rasulullah dan para pengikutnya yang sering disebut dengan masa Salaf (Klasik), atau, lebih lengkapnya al-Salaf al-Shalih (Klasik yang Saleh) atau juga disebut sebagai al-Shadr alAwwal (Inti Pertama)[2]. Yang membedakannya, barangkali, adalah sejauhmana model Islam awal ini dipersepsi apakah secara formalistik atau substantifistik. 
Apa yang disebut-sebut sebagai pendekatan formalistik terhadap model Islam awal ini adalah idealisasi pembentukan tatanan masyarakat Islam sesuai dengan masa Rasulullah SAW, para sahabatnya, hingga para tabi'in berdasarkan peninggalan mereka, yaitu Syari'ah, sebagai model hukum dari tatanan tersebut. Sedangkan apa yang disebut dengan pendekatan substantifistik adalah bahwa Rasulullah SAW dan para sahabatnya itu telah meninggalkan nilai-nilai yang universal, yang dapat diimplementasikan di mana dan kapan pun. Pada pendekatan Islam substantif inilah Nurcholish berdiri. Dengan demikian, bagi Nurcholish, idealisasi akar tradisi politik Islam adalah pada nilai-nilai yang dianut oleh Nabi dan para sahabatnya. Ia menjelaskan bahwa nilai-nilai ideal yang pernah dilaksanakan model Islam awal ini adalah ajaran tentang kesucian "al-dima' wa ' $l$ amwal wa '-a'radl' (hidup, harta dan kehormatan, life, property and honour"). Prinsip-prinsip tersebut ia ambil dari pidato Nabi di haji perpisahan (hajjat al-wada')[3]. Bagi Nurcholish, prinsipprinsip inilah yang sangat mungkin menetes kepada para tokoh kemanusiaan seperti John Lock yang mengemukakan asas-asas "life, liberty and property" dan Thomas Jefferson yang menginspirasi bangsa Amerika dengan prinsip-prinsip "life, liberty and pursuit of happiness"-nya. Kesimpulan Nurcholish tersebut diambil karena ada seorang pemikir zaman Renaissance, Giovani Pico della Mirandola, yang mengakui bahwa ia belajar menghargai manusia dari sumber-sumber Islam[4]. Selain Haji Wada', yang diambil oleh Nurcholish sebagai bukti otentik tradisi politik Islam adalah hijrahnya Nabi SAW ke Madinah yang kemudian membentuk tatanan masyarakat heterogen. Substansialisasi sejarah Islam ini nampak dalam ungkapannya berikut ini: Beliau [Nabi SAW.] pindah ke Madinah atas undangan, malah permintaan, kelompok-kelompok terpenting penduduk Madinah yang kemudian mereka itu bersama kelompok-kelompok lainnya bersepakat untuk menjadikan Rasulullah s.a.w. pemimpin tertinggi mereka. Jadi Rasulullah s.a.w. tidak membentuk masyarakat politik yang eksklusif bagi kaum Muslim. Justru yang ditangani pertama sebagai langkah politik ialah mengatur kerjasama yang baik antar berbagai golongan di kota itu dalam semangat kemajemukan. Kehidupan antar golongan itu diatur atas dasar kepentingan bersama dan secara demokratis, sebagaimana Rasulullah s.a.w. sendiri menjadi pemimpin tertinggi adalah karena proses yang demokratis.

Adalah fakta bahwa Hijrah ke Madinah sering secara benar ditunjuk sebagai titik permulaan berdirinya organisasi politik dalam sejarah Islam. Namun, Nurcholish seperti dalam ungkapan di atas menyatakan bahwa pembentukan masyarakat politik segera setelah Nabi SAW hijrah itu bukanlah pembentukan masyarakat homogen Muslim dengan hukum Islam yang eksklusif, tetapi pembentukan masyarakat yang heterogen dengan tata hukum yang manusia, dalam arti tidak sakral. Hukum yang menjadi persetujuan seluruh elemen masyarakat Madinah tersebut kemudian disebut sebagai Piagam atau Konstitusi Madinah (Mitsaq al-Madinah). Menurut Nurcholish, "ide pokok eksperimen Madinah oleh Nabi ialah suatu tatanan sosial-politik yang diperintah tidak oleh kemauan pribadi, melainkan secara bersama-sama; tidak oleh prinsip-prinsip ad hoc yang dapat berubah-ubah sejalan dengan kehendak pemimpin, melainkan oleh prinsip-prinsip yang dilembagakan dalam dokumen kesepakatan dasar semua anggota masyarakat, yaitu sebuah konstitusi."'[5].

Selanjutnya, asas keadilan yang menjadi landasan prinsip supremasi hukum pun Nurcholish ambil dari tradisi Islam klasik. Selain prinsip-prinsip keadilan yang dikabarkan oleh Al-Qur'an sebagai misi suci para Nabi,[6]. Nucholish pun memperkuat landasan filosofi Qur'ani tersebut dengan implementasi Rasulullah SAW. Ia, misalnya, menyebutkan bahwa Nabi SAW. "tidak pernah membedakan antara 'orang atas', 'orang bawah' ataupun keluarga sendiri." Untuk ini ia 
mengutip Hadits Nabi yang artinya, "Sebenarnya hancur mereka sebelum kamu karena mereka menegakkan hukum atas rakyat jelata dan meninggalkan hukum atas orang besar. Demi Dia Allah-yang jiwaku ada di Tangan-Nya, seandainya Fathimah berbuat jahat maka pasti aku potong tangannya." (Hadits Bukhari, Muslim, Tirmidzi, Abu Dawud, Ibn Majah, Nasa'i, Ahmad, Darimi).[3]. Selain kepada Rasululullah SAW, Nurcholish juga sering merujuk kepada para sahabat Nabi, Abu Bakar misalnya, ia jadikan sandaran model bagi tegaknya nilai "konstitusionalisme" atau "rechstaat" dalam memegang kekuasaan. Kesimpulan ini diambil dari pidato Abu Bakar saat pengangkatannya sebagai Khalifah pertama. Berikut pidato tersebut selengkapnya: Wahai sekalian manusia! Aku diangkat untuk berkuasa atas kamu, padahal aku bukanlah orang yang terbaik di antara kamu. Maka jika aku berbuat baik, bantulah aku! Dan jika aku berbuat salah, luruskanlah aku! Kejujuran adalah amanat, dan dusta adalah khianat! Yang lemah di antara kamu adalah kuat bagiku, sampai aku ambilkan untuknya apa yang menjadi haknya! Yang kuat di antara kamu adalah lemah bagiku, sampai aku ambil hak dari dia, insya Allah. janganlah seorangpun di antara kaum meninggalkan perjuangan! Sebab tidak ada bangsa yang meninggalkan perjuangan kecuali dipukul oleh Allah dengan kenistaan! Taatilah aku, selama aku taat kepada Allah dan Rasul-Nya. Dan jika aku bertindak melawan Allah, maka tidak ada kewajiban atas kamu untuk taat kepadaku![7]. Kemudian, asas musyawarah yang menjadi landasan partisipasi sosial politik masyarakat Islam, dirujuk oleh Nurcholish dari perilaku politik Umar ibn al-Khaththab, Khalifah II. Dengan mengutip sejarawan Mesir Thaha Husain, Nurcholish menulis:

Dan 'Umar itu jika dihadapkan kepada suatu masalah, ia akan mencarinya dalam Kitab Allah, maka jika ditemukannya pemecahan bagi masalah itu ia akan melaksanakannya tanpa ragu; dan jika tidak ditemukannya dalam Kitab Allah, ia akan mencarinya dalam Sunnah Nabi s.a.w., maka jika ditemukannya di situ pemecahannya ia akan melaksanakannya, juga tanpa ragu; dan jika tidak ditemukannya, ia akan berijtihad dengan pendapatnya sendiri dan ia akan laksanakan apa saja yang akan membawa kebaikan orang-orang Muslim. Dan Umar selalu mengajak bermusyawarah para sahabat Nabi s.a.w. kalau-kalau ada pada seseorang dari mereka suatu Hadits dari Sunnah Nabi, atau kalau-kalau ada sebagian dari mereka bisa memberi saran dengan suatu pendapat yang akan membawa kebaikan dan keserahteraan kaum Muslim. Umar memerintahkan para gubernur dan para hakim untuk bertindak seperti tindakannya itu, dan agar tidak seorang pun dari mereka berijtihad dengan pendapatnya sendiri kecuali setelah meneliti dengan seksama al-Qur'an dan Sunnah kemudian tidak menemukan di dalamnya sesuatu yang dapat digunakan untuk mengambil keputusan; saat itulah ia harus berijtihad dan bermusyawarah.[8].

Sahabat Nabi lain yang dirujuk Nurcholish adalah Ali ibn Abi Thalib. Ia dirujuk sebagai orang yang mengeluarkan adagium popular di kalangan ulama mengenai asas pemerintahan yang berkeadilan. Adagium Ali tersebut berbunyi: "Allah menegakkan negara yang adil sekalipun kafir, dan tidak menegakkan negara yang zalim sekalipun Islam," dan "Dunia akan bertahan dengan keadilan bersama kekafiran, dan tidak bertahan dengan kezaliman bersama Islam.'[3]. Selain Nabi dan para sahabatnya, Nurcholish juga seringkali menyebut-nyebut salah seorang tokoh pasca pemerintahan Khulafa al-Rasyidin yang disebut Umar II, yaitu Umar ibn al-Aziz, sebagai tokoh persatuan umat Islam. Umar, misalnya berupaya menyatukan umat dengan mengakomodasi kaum Syi'ah dan merehabilitasi Ali, sehingga sejak beliau Empat Khalifah (tarbi') itu telah menjadi mapan, yaitu: Abu Bakar, Umar ibn al-Khattab, Utsman ibn Affan, dan Ali ibn Abi Thalib.[9].

Dalam upaya melacak akar tradisi politik Islam, Nurcholish nampaknya menemukan bahwa Islam memandang positif arti politik dan kekuasaan, yang kemudian Islam pun menjadi agama para 
penguasa, atau agama yang mempunyai kekuasaan. Tetapi dengan kekuasaan itu, Nabi Muhammad, ataupun para khalifah penggantinya, tidak memandang "kursi" tersebut sebagai wewenang mutlak, baik dalam urusan duniawi, apalagi dalam urusan ketatanegaraan. Wujud pemerintahan Islam Nabi SAW beserta para khalifahnya inilah yang dipuji Robert N. Bellah sebagai sebuah masyarakat manusia yang sangat modern: suatu pemerintahan yang mempunyai sistem politik yang terbuka, egaliter, partisipatif dan berkeadilan sosial.[10].

Ada beberapa hasil penelitian yang mengkaji tentang Nurcholish Madjid, salah satunya adalah penelitian yang dilakukan Nasitotul Janah dengan judul "Nurcholish Madjid dan Pemikirannya (Diantara Kontribusi dan Kontroversi)". Namun paper ini memiliki berbedaan dan keunikan dibandingkan dengan paper lainnya. Fokus yang akan dibahas dalam artikel ini adalah konsep politik Islam kultural perspektif Nurcholish Madjid, yang ditekankan dalam artikel ini adalah islam kultur menurut Nurcholish Madjid.

Dari latar belakang sebagaimana di atas, maka rumusan masalah dalam artikel ini adalag bagaimanakah konsep politik Islam cultural Perspektif Nurcholish Madjid?

\section{B. Metode Penelitian}

Jenis penelitian ini adalah penelitian studi kepustakaan (library research) tentang kajian tokoh, tokoh yang akan dikaji adalah Nurcholish Madjid. Pendekatan dalam penelitian ini menggunakan pendekatan kualitatif yang akan menganalisis lebih mendalam tentang pemikiran Nurcholish Madjid yang berkaitan dengan konsep politik Islam cultural. Tehnik pengumpulan data dalam penelitian ini mengumpulkan beberapa informasi dari beberapa sumber buku primer dan hasil karya ilmiah penelitian-penelitian sebelumnya yang berkaitan dengan penelitian ini.

\section{Pembahasan atau Analisis}

\section{Pemikiran Politik Islam Substantif}

Seperti disebutkan di muka bahwa pemikiran politik Islam dapat dibagi menjadi formalis dan substantif. Formalis adalah mereka yang hendak menegakkan politik Islam dalam bentuknya yang sudah menjadi tradisi Syari'ah. Formalis ini dapat dibagi dua menjadi Fundamentalis dan Tradisionalis. Fundamentalis adalah mereka yang hendak menerjemahkan kehidupan Islam masa pembentukan (Nabi dan para sahabatnya saja) secara literal dan langsung dari al-Qur'an dan alSunnah ke dalam kehidupan modern, walaupun mungkin banyak menghadapi kendala-kendala teknis. Sedangkan Tradisionalis berupaya menegakkan Syari'ah Islam sesuai dengan masa Salaf alShalih melalui bantuan petunjuk imam-imam fiqh dan para ulama selanjutnya hingga kini.

Aksentuasi bahwa substansi atau makna iman dan peribadatan lebih penting daripada formalitas dan simbolisme keberagamaan serta ketaatan yang bersifat literal kepada teks wahyu Tuhan. Sementara pesan-pesan al-Qur'an dan Hadits yang mengandung esensi abadi dan bermakna universal, ditafsirkan kembali berdasarkan runtut dan rentang waktu generasi kaum Muslim serta mengkontekstualisasikannya dengan kondisi-kondisi soaial yang berlaku pada masanya. Kaum substansialis menyadari bahwa negara-negara sedang berkembang atau Dunia Ketiga dewasa ini secara ekonomis, politis, cultural, dan sosial sangat berbeda tempatnya dari Saudi Arabia di zaman Nabi Muhammad. Juga pemahaman literal tentang makna al-Qur'an, penerimaan yang tidak kritis terhadap Hadits dan prinsip-prinsip hukum yang berasal Madzhab-madzhab tradisional, harus diinterpretasikan kembali ke dalam pemahaman modern.[11].

M. Syafi'i Anwar kemudian menjelaskan bahwa pilihan gerakan bagi kaum substantifis dalam iklim politik Indonesia adalah Islamisasi wilayah kultural. Dengan demikian, dari sini 
muncul penamaan baru bagi kaum formalis, yaitu Islam Politik, dan bagi kaum substantifis adalah Islam Kultural. Sedangkan Masykuri memilih istilah Islam Struktural versus Islam Kultural. Apapun namanya, yang jelas Nurcholish termasuk orang yang mencari substansi Islam daripada formalisasi dan simbolisasinya. Pemikiran politik Islam substantifnya sebetulnya telah lama Nurcholish anut, bahkan ketika sebelum sekolah ke Amerika. Yaitu jargonnya pada tahun 1970-an yang cukup popular, yaitu "Islam Yes, partai Islam, No!". Inilah credo Nurcholish: Islam substansinya, bukan formalisasinya! Aksi intelektualnya itu kemudian dibaringi dengan penyampaian istilah "sekularisasi". Seperti diakuinya, "istilah itu diambil dari Sosiologi Agama dan diperkuat oleh ahli sosiologi terkenal Robert N. Bellah.” Namun seperti disesalinya, "orang lebih melihatnya dalam konteks sejarah Eropa." Yang Nurcholish maksud dengan istilah itu sebelunya adalah "bahwa tidak ada yang sakral, kecuali Allah." "Desakralisasi," itulah yang Nurcholish maksud dengan sekularisasi. Nurcholish menyatakan bahwa memang pada tahun 1970-an itu ada argumen yang mengatakan bahwa "kalau tidak mencoblos partai Islam dalam pemilu, maka kita bukan Islam".

Sepulangnya dari Amerika, Nurcholish tampil tidak lagi sebagai aktor intelektual, tetapi lebih sebagai filosof moral, sehingga penyampaiannya bersifat lunak dan elegan. Contoh yang paling menonjol dari pemikiran politik Islam substantifnya Nurcholish sepulang dari Amerika adalah pada Piagam Madinah. Dalam suatu tulisan, misalnya, ia menyebutkan: Bunyi naskah Konstitusi itu sangat menarik. Ia memuat pokok-pokok pikiran yang dari sudut tinjauan modern pun mengagumkan. Dalam Konstitutsi itulah untuk pertama kalinya dirumuskan ide-ide yang kini menjadi pandangan hidup modern di dunia, seperti kebebasan beragama, hak setiap kelompok untuk mengatur hidup sesuai dengan keyakinannya, kemerdekaan hubungan ekonomi antar golongan, dan lain-lain. Tetapi juga ditegaskan adanya suatu kewajiban umum, yaitu partisipasi dalam usaha pertahanan bersama menghadapi musuh dari luar.

Memang, suatu kelebihan pada diri Nurcholish ini adalah pandangan substantifnya dengan refleksi dari sumber-sumber ajaran Islam. Prinsip musyawarah, sebagai suatu prinsip politik Islam, misalnya ia kaitkan dengan tata cara komunikasi politik modern, yaitu keterbukaan. Prinsip itu ia ambil dari perintah Allah kepada Nabi SAW untuk bermusyawarah dengan para sahabat beliau: Adalah karena rahmat dari Allah, maka kau (Muhammad) berlaku lemah-lembut kepada mereka (para sahabatmu). Sekiranya kau kejam dan berhati kasar, tentulah mereka menjauh dari lingkunganmu. Maka maafkanlah mereka, dan mohonkan ampun untuk mereka, serta bermusyawarahlah dengan mereka dalam (segala) urusan. Jika kemudian kau telah ambil keputusan, maka bertawakallah kepada Allah. sesungguhnya Allah cinta kepada mereka yang bertawakal.[12].

Untuk lebih terasanya pemikiran politik Islam substantif dari Nurcholish ini, nampaknya perlu dilakukan suatu perbandingan dalam kasus per kasus pemikiran dengan kaum formalis. Di sini diambil contoh tentang agama kemanusiaan, desakralisasi Pancasila, dan budaya Islam pesisir. Kesemuanya merupakan pandangan yang relatif luput dari perhatian kaum formalis. Sehingga, pemikiran Nurcholish ini betul-betul menjadi suatu alternatif pemikiran Islam, termasuk pemikiran politik Islam.

Apa yang tersirat bagi kaum formalis adalah ayat-ayat keras yang menyatakan bahwa manusia lah yang harus melayani Tuhan. Dengan demikian, hidup adalah demi Tuhan. Padahal, bagi Nurcholish, Islam (agama) itu untuk manusia, yang implikasinya adalah bahwa Islam itu untuk kebaikan semua manusia atau sebagai rahmatan li al-'alamin (rahmat bagi alam raya). Islam 
sebagai agama kemanusiaan itu, bagi Nurcholish, merupakan salah satu pokok (substansi) dari Islam itu sendiri. Pemikiran ini ia alamatkan ke dalam konteks keindonesiaan yang plural, di mana Islam harus menempatkan diri sebagai suatu rahmat.

Karena cita-cita keislaman yang fithri itu sejalan dengan cita-cita kemanusiaan pada umumnya, maka tentunya cita-cita keislaman di Indonesia juga sejalan dengan cita-cita manusia Indonesia pada umumnya. Pernyataan ini memang mengimplikasikan adanya kepercayaan tentang kebaikan alami manusia, dengan sendirinya termasuk manusia Indonesia. saya meyakini betul bahwa pandangan itu merupakan salah satu ajaran pokok agama Islam. Berdasarkan hal itu maka sudah jelas bahwa sistem politik yang sebaiknya diterapkan di Indonesia ini ialah sistem yang tidak hanya baik untuk umat Islam, tetapi yang sekiranya juga akan membawa kebaikan untuk semua anggota masyarakat Indonesia.

Bagi Kaum Muslim formalis, Pancasila nampaknya menjadi "momok" yang menakutkan, sehingga dianggap sebagai "agama baru" bagi bangsa Indonesia. Secara proporsional, dengan pandangan substantifnya terhadap sejarah Islam Nurcholish menyatakan: Sebanding dengan sikap kaum Muslim Indonesia dalam menerima Pancasila dan UUD 45, orang-orang Muslim pimpinan Rasulullah s.a.w. itu menerima Konstitusi Madinah adalah juga atas pertimbangan nilai-nilainya yang dibenarkan oleh ajaran Islam dan fungsinya sebagai kesepakatan antar golongan untuk membangun masyarakat politik bersama. Demikian pula sama halnya dengan umat Islam Indonesia yang tidak memandang Pancasila dan UUD 45 itu sebagai alternatif terhadap agama Islam, Rasulullah s.a.w. dan para pengikut beliau itu pun tidak pernah terbetik dalam pikiran mereka bahwa Konstitusi Madinah itu menjadi alternatif bagi agama mereka.

Kemudian, apa yang tidak bisa dilakukan kaum formalis adalah pencarian akar-akar filosofis dari Islam itu sendiri secara radikal. Inilah peran yang diambil Nurcholish. Substansiasi Islam sebagai ajaran yang egaliter, terbuka, dan demokratis oleh Nurcholish kemudian dialamatkan ke Indonesia. Ia mengatakan bahwa yang sebetulnya demokratis adalah "budaya pesisir" yang rata-rata menjadi kancah budaya Islam bukan "budaya Jawa (pedalaman)" yang menjadi kancah budaya Jawa (Kejawen). Di sini, di masa Orde Baru, jelas pemikiran Nurcholish tersebut menentang arus. [13]. Namun nampaknya memang harus dilakukan untuk mengingatkan bangsa Indonesia, bahwa mereka mempunyai hak untuk menentukan nasibnya sendiri, tidak melulu diatur oleh kekuasaan yang ada (status quo) yang bersifat feodal.

Walaupun Nurcholish tidak menolak sepenuhnya Islam Struktural, juga mengakui pentingnya lembaga-lembaga keagamaan dalam negara seperti Departemen Agama, Pengadilan Agama dan sebagainya, ia tetap tidak mau terlibat secara langsung dalam kegiatan yang berbau politik praktis. Maka ketika ICMI "manggung" dalam perpolitikan Indonesia, ia tetap memilih untuk mengurus Paramadina, walaupun ia sendiri salah satu pendiri ICMI tersebut. Agaknya Nurcholish memang lebih memilih sebagai "guru bangsa" yang mengawal substansi Islam berlaku di negeri yang penduduknya mayoritas Muslim ini.

\section{Hubungan Islam dan Negara}

Pemikiran politik Islam Nurcholish tidak lepas dari posisi yang dipilihnya, yaitu: Keislaman, Keindonesiaan, dan Kemodernan. Maka, dalam masalah Islam dan Negara pun kerap dilatarbelakangi oleh tiga dimensi tersebut. Berikut adalah pemikirannya tentang Islam dan Negara yang secara praktis berada di wilayah pemikiran domestik Indonesia. Pertama-tama Nurcholish mengakui bahwa dalam dimensi sejarah politik Islam di Indonesia, Islam telah menampilkan wujudnya yang eksklusif dan berkesan "galak", sehingga banyak kalangan non-Muslim yang 
meragukan Islam sebagai sebuah sistem politik yang terbuka. Inilah yang kemudian dicoba dijawab oleh Nurcholish. Menurutnya, perdebatan ideologis politik antara "negara Islam" versus "negara nasional atau negara Pancasila" yang memberikan kesan Islam yang eksklusif itu, sebetulnya, adalah peristiwa kesejarahan insidental, bukan pandangan keagamaan yang esensial, dan hanya merupakan akibat-akibat dari bentuk-bentuk tertentu tahap pertumbuhan proses-proses dan strukturstruktur kenegaraan yang masih dalam jenjang formatifnya yang sangat dini.

Oleh karena itu, Nurcholish menyikapi bahwa retorika "negara Islam" dalam sidang-sidang konstituante itu pun harus dipandang dari dimensi kesejarahan. Maka, ketika umat Islam pada waktu itu masih diliputi cita-cita "negara Islam", seperti yang telah diperlihatkan beberapa partai politik Islam, harus dipandang "cocok" dan "benar" menurut ukuran keadaan dan kondisi pada waktu itu, yang masih dalam taraf pencarian jati diri bagi pembentukan negara dan bangsa yang baru mencapai kemerdekaannya[14].

Sikap tersebut adalah sah, karena secara konsepsional, Islam adalah agama yang memandang politik secara positif. Nurcholish menegaskan bahwa sekalipun dalam Islam tidak ada doktrin "pemisahan" antara agama dan negara, tidak berarti bahwa Islam mengidentikkan kekuasaan politik sebagai agama atau sebaliknya, agama dijadikan alat sebagai upaya untuk mencapai kekuasaan politik. Kekuasaan politik bukan tujuan hidup manusia, tetapi hanya sebagai alat untuk mempermudah mencapai tujuan hidup yang lebih hakiki. Karena "Nabi Muhammad SAW pun setelah berhasil membebaskan Mekkah dari kaum musyrikin Quraisy, diperintah Tuhan untuk bertasbih kepada-Nya dan memohon ampun kepada-Nya" demikian Nurcholish[15].

Dengan demikian, lagi-lagi Nurcholish menekankan segi-segi doktrin Islam yang substantif. Yaitu, bahwa Islam adalah agama yang memandang kesatuan antara "yang sakral" dengan "yang profan" (antara agama dengan negara), namun tidak berarti juga keduanya identik. Karena "agama dan negara dalam Islam, meskipun tidak terpisahkan, namun tetap dibedakan: tidak terpisah, namun berbeda", tegas Nurcholish. Oleh karena itu, menurut Nurcholish, dari sudut pandang Islam, pernyataan bahwa Indonesia bukan negara sekuler (bukan negara yang menganut sekularisme yang memisahkan agama dan negara) dan bukan pula negara teokrasi (negara yang kekuasaan politiknya dipegang oleh pendeta atau kaum rohaniawan), dapat dibenarkan, karena memang sejalan dengan ajaran Islam itu sendiri. Karena itu, Nurcholish memberikan penegasan historis bahwa "Dalam Islam, tidak ada suatu rezim yang mengaku sebagai holy atau suci." Itu menunjukkan bahwa dalam sejarahnya, Islam tidak pernah menindas umatnya, bahkan sebaliknya memberikan kelapangan buat ijtihad. Sebaliknya, "di Barat," demikian Nurcholish, "ada Holy Roman Empire, menindas sama sekali”[16].

Selanjutnya, pernyataan bahwa Indonesia bukan negara sekuler dan teokrasi itu diberi penegasan penutup yang bersifat netral, yaitu pernyataan bahwa Indonesia adalah negara yang berdasarkan Pancasila. Bagi Nurcholish, pernyataan seperti itu adalah "cara yang tepat" bagi masyarakat Muslim Indonesia, secara ideologis, dalam memandang negerinya sendiri. Ungkapan itu mengandung juga adanya kesepakatan dan kompromi yang sangat rumit di antara pendiri bangsa, yaitu kompromi antara nasionalis Muslim dengan nasionalis sekuler mengenai ideologi negara yang resmi.

Nasionalis Muslim menginginkan Indonesia yang baru merdeka itu berlandaskan Islam, dan itu berarti mengimplementasikan berdirinya Negara Islam Indonesia (Islamic State of Indonesia). Tetapi nasionalis Muslim sekuler dan non-Muslim menolak gagasan itu, sebab, dan ini merupakan suatu argumentasi yang masuk akal, kaum non-Muslim juga berperan serta dalam perjuangan 
kemerdekaan. Kaum Nasionalis sekuler mengingatkan bahwa menjadikan Indonesia sebagai sebuah negara Islam sama saja merendahkan, secara tidak adil, penganut agama lain sebagai warga negara kelas dua.

Untuk itu, menurut Nurcholish, Pancasila merupakan "jalan tengah" bagi penyelesaian masalah perdebatan ideologis tersebut. Penerimaan Pancasila sebagai landasan negara menunjukkan juga sikap arif pemimpin Islam pada waktu itu dalam menjaga integrasi negara. Malah, jika diteliti lebih jauh, demikian Nurcholish, segala yang terkandung di dalam negara itu sejalan dengan ajaran Islam, meskipun simbol-simbol Islam telah dihilangkan, atau tepatnya dinetralkan. Sebagai salah satu contoh adalah ungkapan pertama "Ketuhanan Yang Maha Esa" pada hakikatnya mengandung tekanan yang sangat khusus menyangkut kualitas monoteistik prinsip keesaan Tuhan, tauhid.

Pancasila dan UUD 1945, sebagai wujud lain Piagam Jakarta yang telah ditempatkan senetral mungkin, akhirnya menjadi basis politik bangsa Indonesia dalam menghadapi heterogenitas budaya, suku, bahasa dan agama di Indonesia. Ini berarti, Pancasila juga menjadi "muara" bagi seluruh agama-agama yang ada di Indonesia, atau yang sering diistilahkan Nurcholish -dengan mengambil istilah al-Qur'an—sebagai "kalimah sawa", titik pertemuan, agama-agama. Umat Islam Indonesia dapat menerima Pancasila itu setidak-tidaknya ditentukan oleh dua pertimbangan. Pertama, nilai-nilainya dibenarkan atau sejalan dengan ajaran Islam; dan kedua, ia berfungsi sebagai titik kesepakatan antara berbagai golongan untuk mewujudkan kehidupan sosial politik bersama.

Kedudukan serta fungsi Pancasila dan UUD 1945 itu bagi umat Islam Indonesia dapat dipandang sama dengan kedudukan dan fungsi dokumen politik pertama dalam sejarah Islam yang dikenal dengan nama Piagam Madinah pada masa awal kehidupan Islam di bawah pimpinan Muhammad SAW di Madinah. Bagi umat Islam Indonesia sendiri, demikian Nurcholish, jika substansi lebih dikedepankan daripada simbol, maka dengan tanpa disadari etika Islam akan berubah menjadi etika bangsa. Dengan demikian, tanpa disadari juga, "negara Islam" yang dicitacitakan oleh para pendahulu politikus Muslim itu bisa terwujud meskipun tidak secara yuridis formal[17].

Demikian juga dengan Pancasila. Penganut agama lain tidak akan menyadari bahwa penggunaan kata "musyawarah", sekedar salah satu misal, adalah nilai Islam yang telah menjadi etika bangsa. Pada akhirnya, secara tidak sengaja mereka "mengakui" Islam sebagai etika bangsanya. Jadi, bangsa Indonesia itu Muslim dalam arti etika. "Etikanya Islam, tetapi tidak harus diberi label Islam" demikian Nurcholish. Apabila etika Islam telah berubah menjadi etika bangsa, maka dengan sendirinya Islam pun akan menjadi sebuah Civil Religion di Indonesia. Ini berarti, Islam Indonesia telah berubah menjadi "Islam Peradaban" yang sangat terbuka, yang melakukan dialog atau konvergensi, untuk kemudian saling mengisi, dengan peradaban lain. Oleh sebab itu, Pancasila harus dilihat sebagai salah satu instrumen penting dari "Islam Peradaban", sehingga berfungsi sebagai titik temu kemajemukan bangsa Indonesia.

Karena Pancasila sebagai salah satu instrumen penting dari "Islam Peradaban", maka Pancasila adalah sebuah ideologi yang berwatak dinamis, tidak statis, karena itu bersifat terbuka. Sifat dan watak inilah yang diharapkan oleh para pendiri bangsa, yang tentunya saham kearifan para politikus Islam sangat berperan, sebagai landasan filosofis bersama, common philosophical ground, sebuah masyarakat plural yang modern.

Menurut Nurcholish, memang dalam hal perumusan formalnya Pancasila tidak perlu lagi dipersoalkan. Demikian pula dalam hal kedudukan konstitutionalnya sebagai dasar negara dalam 
pluralitas bangsa, juga merupakan hal yang sudah final. Namun dalam segi perkembangan prinsipprinsipnya sehingga menjadi aktual dan relevan bagi masyarakat Indonesia yang sedang tumbuh dan berkembang, Pancasila harus dipahami dan dipandang sebagai ideologi yang dinamis.

Oleh karena itu, Nurcholish tidak menginginkan adanya penafsiran Pancasila yang sekalijadi untuk selamanya (once for all). Pancasila juga tidak boleh ditafsirkan oleh badan tunggal yang memonopoli hak untuk menafsirkannya. Sebab, Nurcholish melihat dalam sejarah kehidupan berbangsa dan bernegara, praktek penafsiran suatu ideologi negara oleh suatu badan tunggal sering hanya dijadikan alat legitimasi untuk kekuasaan yang zalim dan sewenang-wenang[18].

Konsekuensi logis dari argumen itu adalah bahwa masyarakat dengan keanekaragamannya harus diberi kebebasan mengambil bagian secara aktif dalam usaha-usaha menjabarkan nilai-nilai ideologi nasional dan mengaktualisasikannya dalam kehidupan masyarakat. Setiap usaha menghalangi kebebasan untuk mengambil bagian dalam menafsirkan ideologi akan menjadi sumber malapetaka, tidak saja bagi negara dan masyarakat Indonesia yang majemuk, tetapi bagi ideologi nasional itu sendiri sebagai titik tolak pengembangan pola hidup bersama.

\section{Demokratisasi dan Oposisi}

Sebagai suatu sistem politik yang sesuai dengan nilai-nilai yang diajarkan Nabi SAW dan para sahabatnya yaitu egalitarianisme, partisipasi, dan keadilan; demokrasi tentu saja menjadi sistem politik yang dianut oleh Nurcholish. Secara filosofis Nurcholish mengatakan:

“...salah satu inti kemanusiaan ialah perkembangan...demokrasi adalah kemanusiaan. Karena itu sebaiknya kita tidak memahami demokrasi sebagai sesuatu yang statis,...demokrasi lebih baik kita pahami sebagai sesuatu yang dinamis, yang menyatu pada masyarakat dalam bentuk proses-proses progresif mengikuti suatu garis kontinum... Kita akan mengatakan suatu masyarakat tidak demokratis jika tidak ada proses demokratisasi... Dan proses itu bisa diukur atau diketahui dalam ... nilai-nilai yang merupakan implikasi masyarakat demokratis seperti hak-hak asasi manusia, kebebasan menyatakan pendapat, kebebasan berserikat, tertib dan keadilan hukum, perwujudan dan kesempatan yang merata, dan seterusnya."

Apa yang terjadi dalam iklim demokrasi di Indonesia, ternyata, demikian Nurcholish, pelaksanaan politik yang dijalankan di Indonesia masih diliputi oleh beragam "kecurangan" dalam Pemilu. Dan yang lebih memprihatinkan dalam pandangannya adalah adanya ketertutupan beberapa pemegang kekuasaan mengenai politik, malah melihat politik sebagai kekuasaan yang tidak boleh diperbincangkan, apalagi dijadikan bahan kritikan. Pandangan yang keliru terhadap politik itu pada akhirnya, menurutnya, akan menjadi penghalang utama bagi kebebasan berbicara serta mengemukakan pikiran, yang ujungnya mempengaruhi juga terhadap alam demokrasi di Indonesia.

Rasa keprihatinan Nurcholish tentang kehidupan politik di Indonesia itu telah mendorongnya untuk melakukan pemikiran politik yang menggegerkan dunia perpolitikan bangsa, tidak saja bagi para pemegang kekuasaan, tetapi juga bagi kalangan politikus dan kaum intelektual. Yaitu pemikirannya mengenai perlunya partai oposisi di Indonesia. Sebuah partai yang diartikannya sebagai sebuah kelompok masyarakat senantiasa harus mengawasi dan mengimbangi kekuasaan yang ada, sehingga terpelihara dari kemungkinan jatuh kepada tirani.

Tetapi Nurcholish pun mengingatkan bahwa jargon politik tidak boleh dipandang sebagai jargon politik semata-mata. Yang lebih penting adalah soal contoh dan keteladanan. Untuk itu, ia mengingatkan agar para penganjur demokrasi, tak terkecuali para pemimpin dan tokoh Islam, bisa memberi contoh dan berperilaku sebagai seorang demokrat sejati. Oposisi memang perlu, tetapi tidak ditujukan sebagai sarana "asal beda pendapat" karena kompensasi akibat ketidakpuasan dan kekecewaan tidak mendapat "kursi" dalam kekuasaan politik. 
Guna menghindari perdebatan dan kecurigaan yang tak beralasan, Nurcholish mengajukan pandangan bahwa oposisi itu berbeda dengan oposisionalisme. Oposisionalisme, menurutnya, menentang sekedar menentang, bersifat subyektif, bahkan barangkali itikadnya kurang baik. Sementara oposisi adalah "mengakui keabsahan suatu pemerintah untuk bertindak dan mengklaim sebagi pemerintah yang baik." Dengan demikian, lanjut Nurcholish, "oposisi hanyalah bertugas untuk mengecek". Dan dalam hubungannya dengan asas kekeluargaan yang dianut negeri ini Nurcholish menyitir peribahasa Jawa, "tega larane, tapi ora tega matine" (tega melihatnya sakit, tapi tidak tega melihatnya mati). Dengan ini ia menyatakan bahwa "oposisi memang tidak ditujukan untuk menjatuhkan pemerintah." Tetapi, lanjutnya, "demokrasi tidak mungkin hidup kalau sistemnya monolitik."

Di sinilah relevansi jargon politik Nurcholish menemukan bentuk artikulasinya secara tepat, bahwa "demokrasi sebagai cara, bukan tujuan". Ini artinya, Nurcholish menghendaki sistem kemasyarakatan yang demokratis yang berdasarkan musyawarah, sebagai wujud pengamalan Pancasila sila keempat. Jika demokrasi berpijak pada kata "musyawarah", maka masing-masing anggota masyarakat bisa saling memperingatkan tentang yang baik dan yang benar.

Tentu saja pemikiran Nurcholish itu bertujuan untuk menegakkan "Keadilan Sosial bagi Seluruh Rakyat Indonesia", yang menurutnya punya kaitan besar dengan perkembangan sosial ekonomi bangsa Indonesia. Terjadinya dorongan ke arah demokratisasi yang lebih maju oleh perkembangan ekonomi memiliki keterkaitan yang sangat erat dengan kehidupan bangsa Indonesia di masa depan. Oleh karena itu, kaum Muslim, yang menjadi bagian terbesar masyarakat tersebut, dituntut sekali perannya dalam meningkatkan proses demokratisasi tersebut.

Apabila demokratisasi berhasil ditegakkan, menurut Nurcholish, akan membawa pada terjadinya "keadilan sosial" yang lebih mencerminkan dimensi kemanusiaan. Terlebih dalam era pembangunan ekonomi yang dijalankan pemerintah Orde Baru, masalah keadilan sosial menjadi dilema tersendiri, yang jika tidak ditanggulangi secara dini dapat berakibat memburuknya tatanan negara dan masyarakat.

Selanjutnya, ia melihat jika masalah keadilan tidak segera dipikirkan pemecahannya, maka akan terjadi konsentrasi sumber daya, khususnya kapital, keahlian dan informasi di tempat-tempat tertentu dan di tangan kelompok atau orang tertentu. Kondisi ini akan menimbulkan ledakan kesenjangan sosial yang sangat lebar, yang akhirnya bisa menyulut "huru hara" sosial. Mengingat hal tersebut, Nurcholish menegaskan bahwa tuntutan mewujudkan keadilan sosial mengharuskan semua anggota masyarakat Indonesia sebagai pejuang-pejuang gigih dalam menegakkan cita-cita luhur tersebut. Tetapi, perjuangan itu tidak boleh dengan cara fanatisme dan tindakan tanpa perhitungan. Sebab, walaupun perjuangan itu demi cita-cita luhur, jika dilakukan secara berlebihan akan mengakibatkan hilangnya kesadaran tentang makna dan cita-cita itu sendiri. Tujuan keadilan sosial dan Pancasila bukan ditujukan untuk membentuk suatu tatanan masyarakat yang baru sama sekali, sebaliknya "cita-cita keadilan dalam Pancasila adalah membangun suatu tatanan masyarakat yang menjamin setiap warganya untuk hidup menurut pilihannya, namun tetap dalam semangat kebersamaan dan kekeluargaan." Karena itu, perjuangan untuk menegakkan keadilan memerlukan manusia yang gigih dan memiliki kearifan dalam bertindak.

Demokrasi memang bertujuan untuk keadilan sosial. Namun, Nurcholish pun mengakui bahwa untuk mencapai tujuan tersebut selalu ada dilema antara "pertumbuhan" dan "keadilan sosial". Dilema ini, bagi Nurcholish, merupakan konsekuensi yang akan menjadi bagian dari modernisasi. 


\section{Kritik atas Pemikiran Politik Islam Nurcholish Madjid}

Ketika menjelaskan tentang Ali Abd Raziq dengan Nurcholish, Dawam Rahadjo menyatakan: "Apa yang ditulis oleh Nurcholish, menurut hemat saya, baru terbatas pada pendekatan pemikiran. Sementara itu, Ali Abdul Raziq sudah masuk ke dalam substansi pemikiran. Dan ini merupakan salah satu kelemahan pemikiran Nurcholish, sehingga ia diserang tanpa menimbulkan tanggapan balik. Pada akhirnya tidak pernah terjadi diskursus.’[19]. Memang, Nurcholish agaknya tidak menempatkan diri sebagai seorang ahli politik yang merumuskan secara programatik apa yang seharusnya dilakukan dalam kerangka politik Islam seperti Ali Abdul Raziq dalam bukunya Islam dan Khilafah, atau Abu al-'Ala al-Maududi dengan bukunya Khilafah dan Kerajaan, atau Sayyid Quthb dengan Ma'alim fi al-Thariq-nya, atau Muhammad Asad dalam The Principles of State and Government in Islam.[20].

Walaupun Nurcholish memang bukan pembuat kerangka politik Islam yang konkret, namun ia telah menunjukkan tekadnya untuk memasukkan etika politik Islam dalam kehidupan politik Indonesia. Apa yang dikemukakan di atas merupakan item-item yang diambil dari sari-sari pemikiran Nurcholish dalam politik Islam. Memang selalu saja ada kritik, tetapi sebetulnya Nurcholish adalah seorang pemikir yang konsisten. Salah satu kritik mengenai pengambilan ide-ide politik Islam dari akar tradisinya datang dari Masykuri Abdillah. Menurut Masykuri, dalam pemikiran politiknya, Nurcholish melakukan ketidakseimbangan antara aspek hukum dengan aspek-aspek lainnya. "Karena," demikian Masykuri, "politik Islam -dan pranata-pranata sosial Islam lainnya - dalam tradisi keilmuan Islam merupakan bagian dari syari'ah (al-ahkam al'amaliyyah)." Dalam hal ini Masykuri betul, karena memang Nurcholish jarang sekali menyebutnyebut tradisi Syari'ah klasik. Namun Masykuri juga menyatakan bahwa dalam sejarahnya, teoretisi politik Islam ada juga yang muncul dari kalangan filosof, yaitu Al-Farabi. Jika dikaitkan dengan Nurcholish, dapat dikatakan bahwa Nurcholish itulah, sekarang, yang mewarisi keahlian Al-Farabi, yaitu di bidang filsafat, yang juga menekuni politik, mengingat Nurcholish memang mengambil spesialisasi filsafat dalam studinya di Amerika. Yang menarik mengenai hal ini adalah pendapat Nurcholish bahwa "Pendekatan bidang politik berbeda dari bidang syari'ah." Karena, menurutnya, "Politik bukanlah bagian dari syari'ah sempit itu, tapi berdiri berdampingan dengannya. Ia lebih mendekati filsafat, dengan dinamika dan wataknya sendiri.”

Kemudian, mengenai Piagam Madinah yang sering digembar-gemborkan Nurcholish sebagai suatu bentuk konstitusionalisme yang datang dari tradisi Islam, Masykuri melihat bahwa umur Piagam Madinah itu sebetulnya pendek, sehingga tidak perlu lagi menjadi asas penting selanjutnya dalam politik Islam. Masykuri nampaknya kurang jeli dalam mendalami buku Nurcholish yang dikritiknya, yaitu buku Cita-cita Politik Islam Era Reformasi (1999). Dalam buku tersebut Nurcholish sendiri sebetulnya mengatakan:

Sekalipun setelah terjadinya peristiwa-peristiwa pengkhianatan Yahudi tersebut resminya Konstitusi Madinah itu sudah tidak berlaku lagi namun prinsip-prinsipnya tetap sah dan diikuti di tempat-tempat lain. Kita juga mengajukan hipotesa-hipotesa tentang apa yang sekiranya bakal terjadi seandainya tidak pernah timbul pengkhianatan-pengkhianatan tersebut. Tapi satu hal sudah jelas, seperti telah dikatakan tadi, yaitu bahwa ketika orang-orang Arab itu melakukan gerakangerakan pembebasan ke daerah-daerah luar Arabia dan mendapatkan masyarakat yang beraneka ragam, maka yang pertama kali mereka lakukan ialah mengatur hubungan antar kelompok itu dengan mencontohkan praktek dan kebijaksanaan Rasululullah s.a.w. di Madinah dahulu. 
Nurcholish menegaskan bahwa dalam sejarahnya, negeri-negeri Muslim, dengan falsafah yang diambil dari Piagam Madinah ini, sampai saat ini menunjukkan sebagai masyarakat majemuk yang harmonis. Dalam pembahasan tentang hubungan Islam dan Negara, Nurcholish masih tetap memegang teguh prinsipnya yang paling kontroversial, yaitu sekularisasi. Dalam memformulasikan istilah sekularisasi Nurcholish sangat terpengaruh oleh Robert Bellah (Beyond Belief) dan Harvey Cox (The Secular City).[21]. Pada satu sisi sekularisasi bisa berarti pemisahan "agama dan negara". Tetapi pada sisi yang lain sekularisasi mengimplikasikan adanya desakralisasi terhadap hal-hal yang tidak tepat untuk disakralkan.[22]. Dengan kata lain, mengakui tradisi manusia sebagai tradisi manusia dan membuatnya terbuka untuk perubahan. Arti yang kedua inilah yang dipedomani Nurcholish dalam hubungan Islam dan Negara.

Seperti dicontohkan di atas, Nurcholish memang melakukan desakralisasi atas pemikiran kebanyakan ahli politik atau politikus Islam bahwa Rasulullah SAW mendirikan negara yang berdasarkan al-Qur'an, sebuah negara Islam (Islamic state). Menurut Nurcholish, Nabi SAW itu mendirikan tatanan politik yang mempunyai nilai-nilai yang universal, yaitu egalitarianisme, partisipasi, demokrasi, dan berkeadilan sosial. Dengan demikian, perilaku politik Nabi dan para sahabatnya itu tidak sakral, dalam arti harus diikuti secara formal. Apa yang dianjurkan oleh Nurcholish adalah pengambilan nilai-nilai mendasar dari perilaku para Salaf al-Shalih itu, kemudian diwujudkan pada tatanan politik yang ada sekarang.

Desakralisasi Nurcholish itu memang telah memunculkan aktivitas baru umat Islam Indonesia, yaitu gerakan Islam cultural. Gerakan Islam kultural inilah yang pada akhirnya gerakan Islam revival (kebangkitan). Hal ini memang tidak terasa secara real politik. Namun kesemarakan Islam telah menimbulkan suasana "santrinisasi." "Proses santrinisasi yang semula berlangsung mengikuti cultural atau keagamaan pada akhirnya secara alamiah dan unintended berhimpit dengan proses santrinisasi politik." demikian Hajriyanto Y. Tohari.

Dalam hal demokratisasi, Nurcholish adalah seorang yang paling rajin menyuarakannya di antara aktivis Islam lainnya. Dialah yang mungkin pertama kali menegaskan bahwa masa depan Indonesia adalah demokrasi, suatu tatanan sosial politik modern. Menurutnya, "demokrasi tersebut memerlukan ideology modern, yang sifatnya open ended, yaitu ideology yang tidak dirumuskan sekali untuk selamanya, tetapi hanya rumusan aspirasi." Demokratisasi inilah, menurutnya, yang menjadi sense of purpose ketiga negeri ini setelah sebelumnya ada sense of purpuse Kemerdekaan dan Nation Building (Soekarno - Orde Lama) dan sense of purpuse Pembangunan (Soeharto - Orde Baru).

Walaupun menurut Nurcholish Soeharto itu "mendengar dan menerima" gagasannya tentang ideologi terbuka, nampaknya kondisi Indonesia memang belum memungkinkan untuk dilakukannya suatu demokratisasi yang lebih massif. Demikian pula konsep oposisinya Nurcholish, belum menghasilkan apa-apa. Bahkan Soeharto sendiri mengatakan bahwa "Indonesia tidak mengenal oposisi". Apalagi oposisi Nurcholish tidak didukung "kekuatan kelembagaan" yang melibatkan "dukungan massa". Praktis oposisi Nurcholish menjadi oposisi soliter (oposisi yang sendirian). Karena itu, demokratisasi dan oposisi Nurcholish lebih merupakan "moral appeal, imbauan moral, daripada kekuatan politik yang aktual dan real."

Karena memang, seperti dibilang oleh Mochtar Pabottingi, dalam rangka kritiknya terhadap Nurcholish, "Tentu tak berarti bahwa melulu dengan visi yang baru segala persoalan besar akan selesai." Menurutnya, bangsa Indonesia memerlukan "prinsip keberpihakan amal-amal konstruktif di bidang sosial, ekonomi, dan politik demi mengangkat golongan lemah dan miskin ia harus 
menolak status quo jika itu melestarikan ketertutupan dan melanggengkan praktek-praktek ekonomi politik yang secara ajeg memihak kepada segelintir golongan dalam masyarakat." Terhadap golongan substantifis seperti Nurcholish, Mochtar menyerukan bahwa mereka harus "menciptakan serta membina sendiri lembaga-lembaga dan sumber-sumber daya matereal mereka untuk dapat mewujudkan ide-ide mereka juga secara mandiri." Maka, masih menurut Mochtar, "kendati para pendukung visi yang baru ini tak berselera dengan kebiasaan menyodorkan 'harga mati' dalam politik, mereka pun harus waspada terhadap sikap politik yang selalu bersedia ditawar-tawar, sebab, seperti ditujukan oleh sebagaian 'pemimpin umat' selama ini, itu lebih mengesankan semangat boneka daripada semangat pemimpin".

Langkah Nurcholish yang bisa dinilai sebagai "boneka" Orde Baru seperti di atas memang bisa dimaklumi, mengingat langkahnya dalam mendukung atau sejalan dengan "de-ideologisasi" dan "depolitisasi" Islam yang dilakukan oleh Orde Baru. Mengenai hal ini Masykuri Abdillah perlu menyodorkan bukti tertulis dari pemikiran Nurcholish. Bukti tertulis tersebut adalah berkisar tentang penilaian positif Nurcholish atas Orde Baru seperti berikut:

“... kiranya cukup beralasan jika kita katakan bahwa di masa Orde Baru menunjukkan banyak segi yang lebih untuk kaum Muslim dibanding dengan Orde Lama. Mungkin hal ini mengandung logikanya sendiri, mengingat bahwa dari awal perkembangannya, Orde Baru mendapat dukungan paling kuat dari kelompok-kelompok beraspirasi politik Islam ketimbang kelompok-kelompok lain. Tentu saja hal ini diingatkan tanpa mengurangi peranan kelompok-kelompok lain”.

Masykuri menilai bahwa memang "kelahiran Orde Baru mendapat dukungan sepenuhnya dari kelompok-kelompok Islam," tetapi kemudian Orde Baru tidak mau mengakomodasi tuntutan umat Islam, "terutama penyelenggaraan Pemilu secepatnya, pemberian status hukum Piagam Jakarta dan rehabilitasi Masyumi." Pemerintahan dukungan ABRI itu kemudian berkoalisi dengan kelompok non-Islam dan abangan hingga awal 1980-an dalam rangka represinya terhadap kelompok Islam. Inilah yang ditentang oleh sebagian besar kelompok Islam.

Pernyataan Masykuri itu betul dari arti konteks kesejarahan, namun apa yang selalu dilakukan Nurcholish adalah hal di balik konteks (beyond context). Inilah pembelaan interpretatif dari Fachry Ali terhadap Nurcholish:

"Akan tetapi, tampaknya, keyakinan moral Cak Nur [panggilan akrab Nurcholish Madjid] telah mengalahkan analisa atas realitas kekuatan-kekuatan politik. Ia dalam hal ini, tak lagi berbicara pada tataran konteks, melainkan telah bersifat beyond Context. Yang diungkapkan adalah keprihatinan moralnya terhadap nasib bangsa di masa kini dan masa depan. Karena itu, seakan-akan membukakan matanya terhadap kemungkinan bahaya yang berbalik kepadanya, dengan lantang Cak Nur berucap di depan publik: "Jangan percayakan nasib bangsa ini kepada niat baik satu dua orang pemimpin. Melainkan kepada sistem yang baik." Jika kita membaca pernyataan tersebut dari perspektif masa kini, maka kalimat itu sesungguhnya adalah ungkapan penolakan moral terhadap rezim yang berkuasa.[23].

Maka, meskipun suara Nurcholish hanya bersifat moral appeal, namun dengan ide-ide substantifnya, Nurcholish telah mendorong banyak aktifnya umat Islam di birokrasi dan sekaligus di politik, tanpa simbolisasi dan formalisasi Islam. Pada gilirannya, Islam pun muncul kembali menjadi kekuatan real politik.[24] Mula-mula melalui ICMI, kemudian, pasca Reformasi, melalui partai-partai politik yang bermunculan "bak cendawan di musim hujan", sampai akhirnya negara Indonesia pernah dipimpin oleh santri.[25]. Kawan seiring Nurcholish di bidang neo-modernisme, yaitu Abdurrahman Wahid, bahkan menjadi presidennya. Kemudian, setelah Abdurrahman dilengserkan, kalangan santri pun masih mempunyai kedudukan yang lumayan, yaitu Wakil Presiden Hamzah Haz dan para menteri santri lainnya. Timbul pertanyaan, “Apakah Islam Kultural sebetulnya mendorong munculnya Islam Politik?” Barangkali demikian, namun kini Islam Politik 
pun sudah tidak nampak lagi berwujud Islam formalistik, seperti dulu. Inilah mungkin karya besar seorang Nurcholish Madjid.

\section{Kesimpulan dan Saran}

Dalam hal politik Islam secara epistemologis, sangat sedikit sumbangan pemikiran Nurcholish. Sebagaimana dalam pemikiran keagamaan, dalam pemikiran politik Nurcholish pun menegaskan perlunya keterbukaan, baik dari kalangan Muslim maupun non-Muslim di Indonesia agar tidak terjadi "harga mati". Masing-masing pihak yang hidup di arena politik Indonesia, menurutnya, harus terus melakukan tawar menawar dan akomodasi kepentingan masing-masing demi terciptanya kepentingan bersama. Pluralisme pemikiran dan keagamaan yang ia anut nampaknya juga dipakai dalam politik, menjadi pluralisme politik. Pluralisme politik memang menjadi faham politik Amerika sejak dulu, dan itu teruji. Tidak heran jika kemudian falsafah pluralisme pun muncul dari Nurcholish yang menyaksikan tegaknya pluralisme di Amerika dari jarak dekat.

Bagi Nurcholish, pluralisme inilah yang kemudian menimbulkan suasana keterbukaan, atau demokratisasi. Demokratisasi ini, pada gilirannya, bisa melahirkan otonomi partai, sebab tiadanya otonomi akan menghapuskan mekanisme kritik yang niscaya bagi suatu sistem demokrasi yang sehat. Partai tidak hanya berguna untuk menjadi sawah-ladang bagi kaum oportunis, melainkan sebagai "investasi politik" yang "tidak terpedaya/terpukau oleh persoalan kekuasaan", melainkan "lebih berpikir strategis" karena yang sesungguhnya dihadapi bangsa Indonesia adalah "persoalan masa depan", demikian Nurcholish.Di tengah pluralisme politik dan demokratisasi inilah suatu oposisi diperlukan, demikian Nurcholish, guna melakukan checks and balances. Oposisi, baginya bukan berarti oposisionalisme, sikap yang selalu oposan. Oposisi yang ia kumandangkan adalah oposisi loyal, terhadap negara.

Jika diperbandingkan dengan para pemikir politik Muslim dunia, memang Nurcholish masih bukan apa-apa. Mereka mempunyai platform politik masing-masing, sementara Nurcholish tidak menekuninya.Walhasil, Nurcholish memang bukan pemikir politik an sich, dalam keadaan ketika pemikiran politik sudah terklasifikasi dan telah dilakukan suatu reduksionisme ilmu. Nurcholish bukan pemikir politik yang menjelaskan apa yang seadanya (what the really is) atau yang menggeluti das sein, tetapi ia berada pada tataran pemikir politik dalam kategori das sollen, yang menjelaskan apa yang seharusnya (what the really ought to be). Dengan demikian sifatnya lebih normatif ketimbang konseptual. Ia bukan representasi dari ilmu-ilmu empirik seperti ilmu politik atau sosiologi, tetapi ia representasi dari ilmu-ilmu abstak seperti filsafat atau percabangannya, etika. Walaupun demikian, seperti disebutkan tadi, analisis sosial telah menjadi perangkat penting pemikirannya. Nurcholish dengan demikian, bukan pemikir politik, tetapi filosof politik Islam di Indonesia. Kata-katanya sloganistisnya lebih mudah diingat, sehingga sulit untuk ditelan masa. Dalam permainan kata (language game) inilah, Nurcholish bagi Indonesia baru (sejak Orde Baru) menghampiri Iqbal bagi India baru, Pakistan. Nurcholish memang telah menampilkan sosoknya sebagai guru bangsa. Demikianlah, Nurcholish telah menjadi icon pemikiran politik Indonesia.

\section{Daftar Pustaka}

[1] O. Roy, Gagalnya Islam Politik. Jakarta: Serambi, t.t.

[2] N. Madjid, Argumen untuk Keterbukaan, Moderasi dan Toleransi (Beberapa Pokok Pandangan Ibn Taymiyah). Jakarta: Yayasan Obor Indonesia, 1986.

[3] Nurcholish Madjid, Cita-cita Politik Islam Era Reformasi. Jakarta: Paramadina, 1999.

[4] Ernst Cassirer, et. al. The Renaissance Philosophy of Man, Chicago: The University of Chicago Press, 1948, h. 223, seperti dikutip Nurcholish Madjid, ibid., h. 260. .

[5] Nucholish, Islam Doktrin, h. 590.

[6] QS. al-Nisa/4:58; Yunus/10:47; dan al-Hadid/57:25. .

[7] Budhy Munawar-Rachman, dalam Nurcholish Madjid, Cita-cita, h. xxii-xxiii. . 
[8] Nurcholish, Islam Doktrin, h. 562. .

[9] Nurcholish Madjid, Islam Doktrin, h. 115, 124, 167, 249, 254, dan 388. .

[10] Nurcholish Madjid, "Ummat Islam Indonesia...," Islam Doktrin, h. xcii.

[11]M. Syafi'i Anwar, Pemikiran dan Aksi Islam Indonesia: Sebuah Kajian Politik Tentang Cendekiawan Muslim Orde Baru, Jakarta: Paramadina, 1995,. .

[12]QS. Ali Imran/3:159 seperti dikutip Nurcholish, Islam: Agama Kemanusiaan, h. 195. .

[13]Fachry Ali, "Nurcholish Madjid sebagai 'Guru Bangsa"” dalam Sukandi (ed.), Tharikat Nurcholisy, h. xxvii. .

[14]Nurcholish Madjid, "Persoalan Modernisasi di Kalangan Umat Islam Indonesia: Dari Sudut Pandang Seorang Partisipan," dalam Imam Ahmad, Sharon Siddique dan Yasmin Hussain (ed.), Islam di Asia Tenggara Perspektif Kontemporer, Jakarta, LP3ES, 1987, h. 544. .

[15] Nurcholish Madjid, "Kebebasan Nurani (Freedom of Conscience) dan Kemanusiaan Universal sebagai Pangkal Demokrasi, Hak Asasi dan Keadilan," dalam Elza Peldi Taher (ed.), Demokratisasi Politik, Budaya dan Ekonomi, Jakarta: Paramadina, 1994, h. 126. .

[16]Nurcholish Madjid, Dialog Keterbukaan: Artikulasi Nilai Islam dalam Wacana Sosial Politik Kontemporer, Jakarta: Paramadina, 1998, h. 289. .

[17] Nurcholish Madjid, “Menatap Islam Masa Depan,” Ulumul Qur'an 1 Vol. V, 1994, h. 53. .

[18] Nurcholish Madjid, "Islam di Indonesa dan Potensinya sebagai Sumber Substansi Ideologi dan Etos Nasional," dalam Budhy Munawar Rahman (ed.), Kontekstualisasi Doktrin Islam, Op. Cit., h. 568-9. .

[19]Edy A. Effendy, Dekonstruksi Islam Mazhab Ciputat, Bandung: Zaman Wacana Mulia, 1999, h. xiv. .

[20] Mohammad Taufiq. Social Justice in Western and Islamic Thought: A Comparative Study of John Rawl's and Sayyid Qutb's Theories of Social Justice. Diss. Jabatan Akidah dan Pemikiran Islam, Akademi Pengajian Islam, Universiti Malaya, 2010, pp. 75-85. .

[21]Bellah, Robert N. Beyond belief: Essays on religion in a post-traditionalist world. Univ of California Press, 1991; Cox, Harvey. The secular city. 1966. .

[22] Greg Barton, "The International Context of the Emergence of Islamic Neo Modernism in Indonesia" dalam M. C. Ricklefs (ed.), Islam in the Indonesian Social Context, Annual Indonesian Lectures Series No. 15, Melbourne: CSEAS Monash University, 1991, h. 77. .

[23] Fachry Ali, dalam Tharikat Nurcholisy, op. cit., h. xxvii. .

[24] Martin van Bruinessen, "Genealogies of Islamic radicalism in post-Suharto Indonesia" dalam South East Asia Research, Vol. 10, No. 2, July 2002, h. 142. .

[25] Nurcholish Madjid, Tradisi Islam: Peranan dan Fungsinya dalam Pembangunan di Indonesia, Paramadina, Jakarta, 1997, hal. 51-62). Hajriyanto Y. Thohari, dalam Tharikat Nurcholisy, op. cit., h. 377. 
Fikri: Jurnal Kajian Agama, Sosial dan Budaya

Mohammad Rahman 